\section{Party System Institutionalization in Ghana and Senegal}

Journal of Asian and African Studies 48(5) 577-593 (C) The Author(s) 2012 Reprints and permissions: sagepub.co.uk/journalsPermissions.nav DOI: $10.1177 / 0021909612465720$

jas.sagepub.com

@SAGE

\author{
Anja Osei \\ University of Konstanz, Germany
}

\begin{abstract}
This paper presents a comparative case study of party system institutionalization in Ghana and Senegal. Both countries experienced a democratic change in government in the year 2000, but while positive development has continued in Ghana, democratic quality in Senegal decreased over time. Can the concept of party institutionalization help to explain this diverging development? Four dimensions of party system institutionalization are systematically compared: regularity, social roots, legitimacy, and party organization. It is found that party competition in Ghana is characterized by high stability and a low number of parties. The major parties are organized throughout the country and have definable support bases with deep historical roots. They give orientation to voters and are perceived as legitimate actors. In Senegal, in contrast, the party system is fluid and less predictable. Parties are not structured along social cleavages and many of them are weakly organized and highly personalistic. In summary, the case studies support the assumption that an institutionalized, well-structured party system in which relevant social cleavages are translated into electoral alternatives is positively related to democratic quality.
\end{abstract}

\title{
Keywords
}

Cleavages, democratization, ethnicity, legitimacy, party organization

\section{Introduction}

There is wide agreement that parties and party systems play an important role in the process of democratization. The link between party system properties and democracy is nevertheless controversially discussed. Increasing attention is now being paid to the concept of party system institutionalization (PSI). Institutionalization is the process by which 'organizations and procedures acquire value and stability' (Huntington, 2006: 12). Based on their analysis of Latin America, Mainwaring and Scully (1995: 1) argue that modern mass democracy is difficult to sustain without an institutionalized party system. Studies that have applied their approach to African cases support this view (Kuenzi and Lambright, 2005; 2001; Basedau, 2007). Thus, although African party systems sometimes pose a challenge to traditional ideas in party research, there is reason to believe that 'stable interactions make democracy work' (Lindberg, 2007: 241).

\section{Corresponding author:}

Anja Osei, Department of Politics and Management, University of Konstanz, P.O. Box 90, Konstanz 78457, Germany. Email: anja.osei@uni-konstanz.de 
The purpose of this paper is to present a comparative study of party system institutionalization in Ghana and Senegal. Both countries experienced a democratic change in government in the year 2000. However, while positive development continued in Ghana, democratic quality in Senegal decreased under the reign of Abdoulaye Wade. Although Wade was finally defeated in the 2012 presidential elections, the immediate run-up to the polls was marred by violent incidents. The major question that this paper addresses is whether the perspective on party system institutionalization can help to explain the differences in democratic development between the two countries.

The paper proceeds as follows: the second discusses some theoretical challenges for party research in Africa in relation to the concept of PSI. The third section introduces the methodological approach. The fourth and fifth sections apply the comparative framework to the case studies, and the final section summarizes the results.

\section{African Party Systems: Puzzles and Labyrinths}

Contemporary research suggests that party systems in Africa are 'puzzling phenomena' (Mozaffar and Scarritt, 2005). They are often characterized by one-party dominance, exhibit little ideological competition, and do not reflect the classical cleavages (urban/rural, church/state, labour/capital, and centre/periphery) that have shaped Western European party systems (see Lipset and Rokkan, 1967). Moreover, there seems to be no straightforward relationship between party system characteristics and variations in democratic development (Karvonen and Anckar, 2002). From these observations, many authors have concluded that African party systems are different from those in industrial democracies (Manning, 2005: 708).

Such claims can be traced back to Sartori, who coined the metaphor of the 'African labyrinth' for what he perceived to be highly fluid and unstructured party systems (Sartori, 2005: 248). In his perspective, these polities cannot be 'incorporated under Western categories, nor can they provide categories for the West' (Sartori, 2005: 266). Current scholars have become even more sceptical regarding the applicability of 'Western biased' concepts of party research to Africa (Erdmann, 2004). The concept of institutionalization has not been spared from this type of critique, because it is a 'distillation of the distinctive experience' of industrialized democracies (Randall and Svasand, 2002: 6). These reservations are understandable, but they create a dilemma: while the development of new and more area-sensitive concepts is necessary and desirable, this task requires more and better data - and data collection, in turn, requires conceptual guidance (Basedau et al., 2007: 287).

Mainwaring and Scully's operationalization of PSI has the advantage of being explicitly grounded in the context of democratizing countries. The authors identify four dimensions of institutionalization: (1) regularity of party competition; (2) stable roots in society; (3) legitimacy of parties and elections; and (4) party organization (Mainwaring and Scully, 1995: 4f). They argue that the predictability and stability of an institutionalized party system positively contributes to democracy (Mainwaring and Scully, 1995: 4).

A first application of this concept to Africa in a large-N design by Kuenzi and Lambright (2001) indicates evidence for this positive relationship. At the same time, this study underlines the conceptual and empirical dilemma described earlier. Because of a lack of comparable data, the authors dropped the indicator of party organization from their research design and assessed the criterion of social roots using a measurement of party age. However, party age can be a problematic indicator because it biases the analysis in favour of countries that introduced formal multi-party systems relatively early; thus it is no surprise that Botswana, Gambia, and Senegal have some of the highest levels of PSI in this analysis. As a consequence, the relationship between democracy and PSI becomes somewhat tautological: countries with comparatively long experiences with multi-party 
systems are assigned higher PSI scores, and higher PSI scores are then viewed as being positively related to democracy.

This demonstrates that a great deal more groundwork is necessary to fill in the research gaps in investigation of social roots and party organization. Small-N studies can make a major contribution in this regard, as they offer a thick and holistic approach that can help us to better understand the link between PSI and democratization.

\section{Case Study Design}

Careful case selection is the backbone of any meaningful comparison. With regard to this paper's question of interest, theory predicts that higher levels of party institutionalization correspond to higher levels of democracy. An ideal test of this proposition would be a most similar systems design. Following Mill's method of difference, we should select cases with different values for the dependent variable and similar values for all but one of the possible causal variables (see, among others, Levy, 2008: 10). If we could find two cases that are very similar to each other, except that case A has a high level of democratic quality and a high level of PSI while the reverse is true for case B, then we could safely argue that there is a causal relationship between the dependent and the causal variable. However, these strict requirements are seldom fulfilled in the social sciences, and it is difficult if not impossible to find cases that are 'truly comparable' in Mill's sense (Lieberson, 1992).

This qualification applies to Ghana and Senegal as well. The countries differ in the dependent variable democratic quality (see Figure 1). Ghana is one of the most democratic countries in Africa today, whereas Senegal, long held to be a success story, lost its status as a 'free' country in the 2008 Freedom House Report. The run-up to the 2012 elections was especially troubled and even marred by violence. There is some hope that democracy will thrive again after the victory of Macky Sall, but because it is too early to make any judgement, this paper focuses on the time before 2012 .

The two countries also have important aspects in common: both are situated in West Africa and are comparable in many economic and social indicators. ${ }^{1}$ In addition, both countries are multiethnic and home to a variety of religious groups. Despite their similarities, they do not fit neatly into the most similar systems design, as there are a number of differences in their political history and institutional arrangements.

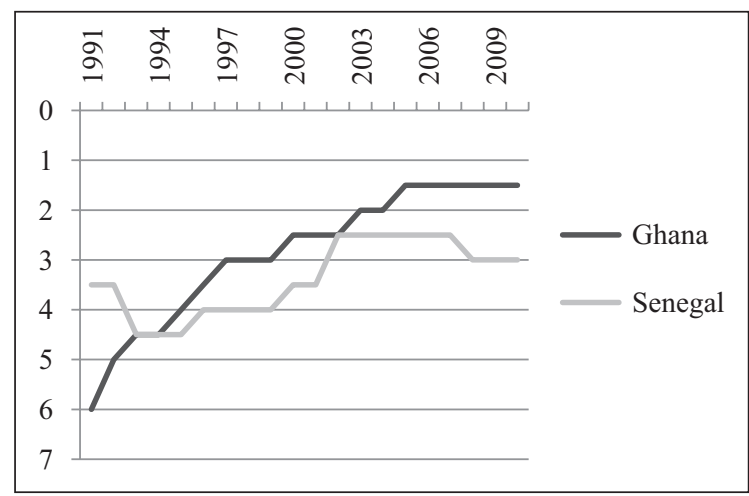

Figure I. Freedom house ratings Ghana and Senegal, |99|-20I0. 
Such 'imperfect' comparative designs may be the norm rather than the exception. As Hall (2003) argues, the causal structures of the real world do not conform to the demanding assumptions of the classical comparative method: not only are social phenomena such as democracy multicausal and dependent on a number of factors other than party institutionalization, but complex chains of causality also present obstacles to analysis. Thus, while PSI may facilitate democracy, there are simultaneously other factors that facilitate PSI. Causal complexities such as equifinality and path dependence therefore pose a number of challenges for comparative researchers (Bennet and Elmann, 2006: 14). A combination of process tracing and systematic case comparison has been suggested as a possible solution to this problem (Bennet and Elmann, 2006: 14). Process tracing is a method of within-case analysis that seeks to identify the mechanisms that connect causes and outcomes (George and Bennet, 2005). Systematic case comparison asks a set of standardized, general questions in each case (George and Bennet, 2005: 69).

This paper follows the suggestion to combine these methods. Process tracing is used to give a thick description of how party system institutionalization and democracy are linked in each of the countries. In addition, the comparison will be structured by using the operationalization of PSI proposed by Mainwaring and Scully. The paper draws on field work conducted between 2006 and 2008. Data were collected in semi-structured interviews with party representatives at various levels of the party hierarchy in Ghana and Senegal. The three major parties in each country were included: the New Patriotic Party (NPP), National Democratic Congress (NDC), and People's National Convention (PNC) in Ghana, and the Parti Démocratique Sénégalais (PDS), Parti Socialiste (PS), and Alliance de Forces de Progrès (AFP) in Senegal. Although a great deal of work is still necessary, it will be possible to present at least a few comparative assessments of ideological and organizational development. In addition, election data and data from the Afrobarometer Survey, round four, are examined. ${ }^{2}$

The first criterion of PSI, the regularity of party competition, is generally measured using the Pedersen Index of Volatility, which gives the net change in seats or votes for a party from one election to the next. This measure can be very informative in large- $\mathrm{N}$ comparisons but remains too descriptive for a small-N design. Because regularity involves a time dimension, the focus of this paper will therefore be the question of how contemporary patterns of party competition developed over time.

The second criterion, stable roots, presents a complex problem. Mainwaring and Scully (1995: 9ff) propose to use opinion surveys to measure the strength of party identification among voters, but they also examine the extent of personalism and the age of parties. By noting that institutionalized party systems create linkages between parties, citizens, and organized interests, the authors open the doors to a broader understanding of the social roots of parties (Mainwaring and Scully, 1995: 9ff). With regard to Africa, it is unclear whether parties reflect social interests at all. Many scholars would agree with Manning (2005: 722), who argues that parties are instead the creations of elites who then capitalize on existing cleavages. However, she continues, in both cases 'the lines of political competition may well have considerable staying power' (Manning, 2005: 722). Thus it is necessary to take a close look at the socio-economic, regional, and ethnic factors that could possibly affect voting patterns in our two cases, and to identify how parties position themselves along such cleavages. The findings will be supported with data from the Afrobarometer Survey. The discussion of personalism, however, we shift to the fourth criterion of party organization.

The third criterion can be assessed with survey data measuring the strength of legitimacy of and trust in political parties. Again, Afrobarometer data will be used to evaluate this aspect. In addition, we will look at instances of opposition boycotts and at the general willingness of parties to respect democratic norms. ${ }^{3}$ 
Table I. Composition of the legislative assembly in Ghana, 1996-2008'.

\begin{tabular}{lcccr}
\hline & 1996 & 2000 & 2004 & 2008 \\
\hline NPP & 61 & 100 & 128 & 108 \\
NDC & 133 & 92 & 94 & 115 \\
PNC & 1 & 3 & 4 & 2 \\
CPP & Not in existence & 1 & 3 & 1 \\
PCP & 5 & - & - & - \\
Independent & - & 4 & 230 & 4 \\
Total & 200 & 200 & 1 & 230 \\
\hline
\end{tabular}

Finally, the fourth criterion states that parties should be well financed and have active memberships, a professionalized staff, clear procedures for selecting leaders, and solid party discipline. As noted earlier, research on this topic has been scarce. Based on information gathered in the field work in Ghana and Senegal it is nevertheless possible to present a comparative evaluation of parties in the two countries. A short discussion of personalism is included in this section.

\section{Party System Institutionalization in Ghana}

\section{Regularity}

Ghana's party system is marked by stability and a comparatively low number of parties (Table 1). Two turnovers have taken place since the reintroduction of multi-party politics in 1992. In 2000, power passed from the NDC to the NPP, returning to the NDC in 2008.

An early split in the nationalist movement at the eve of independence paved the way for this pattern of competition. The first political party, the United Gold Coast Convention (UGCC), was politically moderate and dominated by the wealthy and educated Akan elite in southern Ghana. In 1947 Nkrumah left the UGCC to found the radical, left-wing Convention People's Party (CPP), which led Ghana to independence in 1957. Only a few years later, Nkrumah was ousted by a military coup, and between 1964 and 1992 Ghana experienced a rapid alternation of various military and civilian governments. After a period of military rule under Jerry John Rawlings, founding elections were held in 1992. Although party development was interrupted now and then over the years, each new republic saw the resurgence of two political traditions: the Busia-Danquah tradition (as the successor to the UGCC) and the Nkrumahists (following the spirit of the CPP). Each party of the Busia-Danquah tradition claimed to stand for the rule of law, liberal democracy, a freemarket economy, and individual freedom. In contrast, the Nkrumahists presented themselves as defending the interests of the common man (Jonah, 1998: 90; Nugent, 2007: 260). As soon as the ban on political parties was lifted 1992, the old distinctions resurfaced, with the NPP representing a revival of the Busia-Danquahists, in opposition to a number of splintered Nkrumahist parties. This time, however, competition was altered by the presence of the NDC, a party formed to secure Rawlings' re-election. At the beginning, the NDC placed itself in the middle, between the two older traditions, but it soon began to take over the space on the left that had once belonged to the now seriously weakened Nkrumahists. In fact, the NDC and the Nkrumahists share a certain anti-elite stance and a focus on the poor, vulnerable, and socially disadvantaged as their targeted support base. In addition, the NDC has absorbed some Nkrumahist networks and has attempted to exploit the memory of Nkrumah in several ways (Amponsah, 2006: 290; Nugent, 2007: 261). 
Table 2. Ethnic composition of NDC and NPP voters (in \%).

\begin{tabular}{llrccc}
\hline & Akan & Ewe & Ga & Dagomba & other \\
\hline NPP voters & 60.3 & 8.3 & 6.4 & 4.0 & 21 \\
NDC voters & 22.4 & 31.8 & 13.9 & 11.3 & 20.6 \\
\hline
\end{tabular}

Although the legislative presence of the remaining Nkrumahist parties (PNC and CPP) shrunk to only three seats in 2008, the growth of the NDC has restored the characteristic polarization in Ghanaian politics. It can thus be argued that party formation at independence created a certain path of dependence that has influenced the patterns of party development up to the present day.

\section{Stable Roots}

Political party traditions provide a necessary background for understanding the complexity of voting patterns in Ghana. Each of the traditions has an ethnic, regional, and socio-economic support base. These factors interact in complex ways, providing the two major parties the opportunity to build distinct images.

In 2004, the NPP won all regions in which the majority of the population was of the Akan ethnic group (Ashanti, Brong-Ahafo, Eastern, Western, and Central regions), plus the capital city of Accra. The NDC, in turn, won all non-Akan regions: Volta, Northern, Upper East, and Upper West. The divergent ethnic composition of NDC and NPP voters is further confirmed by data from the Afrobarometer (see Table 2).

Before jumping to the conclusion that the NPP is an Akan-party, it should be noted that the Akan are not a homogeneous group, but rather a 'potpourri of smaller groups', including Ashanti, Fanti, and other communities (Frempong, 2000: 144). While Akan support for the NPP was overwhelming in 2000 and 2004, the Akan have not always formed a voting bloc in favour of the BusiaDanquah tradition. Since independence, only the Ashanti and the Eastern regions have been won by a party from this tradition in every election. In almost all the other elections, some Akanspeaking subgroups in the Central, Brong-Ahafo, and Western regions have voted for other parties.

More telling than a simple ethnic headcount is the fact that the Akan affiliation with the NPP reflects differences in regional development. The Akan regions are generally better off than the non-Akan regions. Greater Accra, Ashanti, Eastern, Western, and Central are the most highly developed regions, followed by the Volta region and Brong-Ahafo; the Northern, Upper East, and Upper West regions are at the bottom end of the scale (Gyimah and Asante, 2004). The discrepancies between the more urbanized and more highly developed southern regions and the north are to a large extent a legacy of uneven colonial infrastructure. This gap in development has still not been narrowed, and the feeling of being underprivileged prevails in the north in particular. In addition, the Ewe of the Volta region have historically had a tense relationship with the Akan. Ethnic tensions arose in the Second Republic under the presidency of Busia, one of the namesakes of the Busia-Danquah tradition. Busia's cabinet was clearly imbalanced in favour of fellow Akans, and nearly all Ewes were removed from positions of power. This changed significantly after Rawlings' military coup in 1979. Rawlings, himself half-Ewe, proclaimed a revolution against the corrupt establishment which was especially well received in the Volta region. Today, the region is a firm stronghold of the NDC. However, this represents regional rather than ethnic voting: the NDC is 
Table 3. Living conditions of NPP and NDC voters.

\begin{tabular}{llll}
\hline & Good & Neither good nor bad & Bad \\
\hline NPP voters & 50.2 & 9.5 & 40.4 \\
NDC voters & 31.8 & 5.7 & 62.4 \\
\hline
\end{tabular}

popular not only among the Ewe but also among the Akan and other ethnic minorities (Jonah, 1998).

The assumption that there are not only regional and ethnic dynamics but also socio-economic cleavages in voting behaviour is supported by a study of core and swing voters undertaken by Lindberg and Morrison. They find that 'rural belongingness, low levels of education, farming and working-class jobs, and low income' are typical for NDC voters, while the reverse is true for the NPP (Lindberg and Morrison, 2005: 583). The Afrobarometer data also show that NPP supporters appear to live under better conditions than NDC supporters do (see Table 3).

These cleavages are reflected in the official party ideologies. Although programmatic competition is not very pronounced, Ghanaian party representatives are generally able to give a clear outline of their political objectives. In the qualitative field interviews, the NPP was remarkably coherent. All interview partners stated that their party stood for the rule of law, liberal democracy and freedom. The NDC portrayed itself as a 'centre-left' or social-democratic party. Phrases such as 'defending the poor' and 'working for the welfare of the people' were frequently used to describe the character of the party. This does not necessarily mean that there are substantial ideological differences between the parties. In practice, the NPP also embraces social-democratic policies, and the NDC is not principally opposed to market reform. However, the master narratives of the two parties are framed in opposition to each other.

From this perspective, the polarization between the NPP and the NDC along the Akan/nonAkan divide is based on a multifaceted conflict between a centre in which wealth and power are concentrated and the more remote and deprived regions. The Busia-Danquah tradition has historically represented one side of this conflict line, while the other side was originally represented by the Nkrumahists, who have now been replaced by the NDC. Thus patterns of voter mobilization in Ghana bear some resemblance to the centre-periphery conflict described by Lipset and Rokkan as unfolding between dominant national elites and more peripheral regions, linguistic minorities, or culturally threatened peoples (Lipset and Rokkan, 1967).

\section{Legitimacy}

In Ghana, political parties are the objects of passionate support. According to the Afrombarometer data, $66.3 \%$ of respondents feel a close connection to one of the political parties. ${ }^{4}$ Party alignments tend to be stable: Lindberg and Morrison (2005) found that only $18 \%$ of voters could be classified as swing voters. According to the Afrobarometer data, Ghanaians place a good deal of trust in their parties, especially in the ruling party (Table 4). ${ }^{5}$

At present, the political parties themselves are largely committed to the democratic process. Only in 1992 did the victory of Rawlings in the presidential elections spark some controversy. Although the opposition parties claimed electoral fraud and boycotted the parliamentary elections, international observers could find no systematic irregularities. From 1996 onwards, however, political parties generally played by the rules of the game. Especially noteworthy is the fact that the 
Table 4. Trust in political parties in Ghana (in \%).

\begin{tabular}{lll}
\hline & Ruling party & Opposition parties \\
\hline A lot & 43.2 & 21.8 \\
Just a little/somewhat & 43.4 & 53.3 \\
Not at all & 28.7 & 23.1 \\
\hline
\end{tabular}

former military ruler Rawlings guaranteed a smooth transition after the electoral defeat of his party in 2000. Another victory of democracy was obtained in the dramatic second round of the 2012 presidential elections, in which the NDC candidate Atta-Mills and Akufo-Addo from the NPP were running a very tight race. The atmosphere was heated, and for a brief moment after losing AkufoAddo seemed unwilling to acknowledge the results. He set in motion legal proceedings in order to stop the Electoral Commission from announcing an official winner, but the Ghanaian High Court refused to accept the case. Ultimately, the NPP decided to take no further steps, thus clearing the way for the second turnover of power following the founding elections.

\section{Party Organization}

The two major parties (NPP and NDC) are both well-organized on the ground and possess a network of party branches throughout the country. It is impossible to provide reliable numbers for party membership, because a distinction between members and followers is difficult to make. Formal party affiliation includes membership cards and the payment of party dues. In reality, however, payment practice is poor, especially in rural areas. ${ }^{6}$ Only aspirants for parliamentary slots and posts in the party hierarchy are expected to have paid their dues and/or donated money before standing for office, but even this regulation is applied in a relaxed fashion. More generally, there are deficits in intra-party democracy, accountability, and communication: official procedures for intra-party elections are not always observed, and irregularities frequently occur.

These problems notwithstanding, political parties in Ghana do not validate the cliché that African parties are weakly organized. The field interviews revealed the effort of the NPP to professionalize its organization not only in its core areas but also in the regions where the party is weak. In Hohoe North in the Volta region, for example, the party has a well-equipped office with a paid full-time secretary and daily opening hours, and organizes a number of activities, including football matches for the youth. The NDC, albeit a bit less vibrant and less professional, has an equally solid organizational structure to build on. In both parties the intensity of party meetings and other regular activities varied regionally. While some branches hold weekly meetings, others do so only monthly or on special occasions. To a great extent, party life depends on the commitment of the local personnel. Party branches receive little financial support from the central organization, and thus most activities must be financed by local chairmen and supporters. The lack of resources hits small opposition parties the hardest; the Nkrumahist parties PNC and CPP can operate only a rudimentary party apparatus.

Finally, a comment on personalism is in order. Personal qualities of presidential and parliamentary candidates do matter in Ghana, but they seem to be less important than party loyalties. None of the NPP presidential candidates in the Fourth Republic was overly charismatic. The NDC, in contrast, was built around the magnetic personality of Rawlings, the party's founder, who nevertheless stepped down after serving two presidential terms. His successor, Atta-Mills, lost two elections against the NPP's Kufuor in 2000 and 2004. Surprisingly, he was finally able to shake off his 
Table 5. Composition of the Senegalese legislative assembly, I983-20I2.

\begin{tabular}{|c|c|c|c|c|c|}
\hline & 1983 & 1998 & 2001 & 2007 & 2012 \\
\hline PS & 111 & 93 & 10 & Boycott & - \\
\hline PDS & 8 & 23 & 89 & $13 \mid$ & 12 \\
\hline \multirow{3}{*}{$\begin{array}{l}\text { Benno Bokk Yakar Coal. } \\
\text { others }\end{array}$} & - & - & - & - & 119 \\
\hline & RND I & $\begin{array}{l}\text { URD II } \\
\text { AJ PADS } 4 \\
\text { LD MPT } 3\end{array}$ & $\begin{array}{l}\text { AFP II } \\
\text { AJ PADS } 2 \\
\text { URD } 3\end{array}$ & $\begin{array}{l}\text { Boycott of major } \\
\text { opposition } \\
\text { parties }\end{array}$ & $\begin{array}{l}\text { Bokk Gis Gis } 4 \\
\text { MCRN } 4 \\
\text { MRDC } 2 \\
\text { PVD } 2\end{array}$ \\
\hline & & $\begin{array}{l}6 \text { other parties } \\
\text { with one seat } \\
\text { each }\end{array}$ & $\begin{array}{l}5 \text { other parties } \\
\text { with one seat } \\
\text { each }\end{array}$ & $\begin{array}{l}\text { I3 parties with } \\
\text { one to three } \\
\text { seats }\end{array}$ & $\begin{array}{l}8 \text { parties with } \\
\text { one seat }\end{array}$ \\
\hline
\end{tabular}

image as a loser and win the 2008 elections. His victory can be attributed to the party's overall campaign strategy and (more importantly) to disenchantment with the NPP rather than to his personal charisma. Party loyalty, not personality, seems to be the decisive factor in Ghanaian elections. This is even more evident at the local level. In the Volta region, loyalty to the NDC is so strong that 'if the NDC puts a sheep as a candidate, people would vote for the sheep'. ${ }^{7}$ The same applies to the NPP in the Ashanti region. However, undecided voters might well be influenced by a charismatic leader.

\section{Party System Institutionalization in Senegal}

\section{Regularity}

Senegal has always had a dominant party system characterized by a ruling party with a strong parliamentary presence and a number of small opposition groups. Table 5 illustrates the composition of the National Assembly from 1983 to 2012.

These figures demonstrate that both the PDS and the PS were once in a dominant position but lost it over time. In addition, the number of small parties has increased rapidly over time. Currently, the parliament features 13 parties, seven of which have only one seat. ${ }^{8}$

The historical evolution of Senegal's party system can help us to understand these developments. After its independence in 1960, the country became a de facto one-party state under the PS. President Senghor, himself a Catholic, built excellent relationships with the other religious communities in the country, especially with the leaders (marabouts) of the powerful Islamic Sufi brotherhoods. Sufism is a mystical version of Islam in which the marabouts are viewed as holy men to whom disciples owe their allegiance. In exchange for access to state resources, the marabouts mobilized their disciples for the ruling party (Fatton, 1987: 97). The PS benefitted strongly from this clientelistic relationship and was even able to allow some electoral competition without losing its hegemonic position. In 1979 Senghor decided to introduce an ideologically restricted multi-party system (multipartism limité) that recognized a liberal, a communist, and a social-democratic party. Under Senghor's successor Diouf this system was transformed into an unrestricted multi-party system.

While this moderate liberalization helped to contain and accommodate the opposition for many years, the PS's rule began to crumble in the late 1980s. Dissatisfaction with the party rose steadily, and even the marabouts began to withdraw their direct political support. In 2000 the opposition politician Abdoulaye Wade won the elections. After a blazing start, Wade's rule soon began to 
show authoritarian tendencies (Mbow, 2008). Since then, power in Senegal became more and more centralized, and nearly all institutions came under the influence of the executive branch. In addition, there were setbacks in freedom of the press and freedom of association, as well as incidents of repression against opposition figures.

Since 2000 , the number of parties has virtually exploded. The major sources of party proliferation are internal power struggles and succession crises. Prominent examples include the ex-PS politician Moustapha Niasse (founder of the AFP) and the two PDS dissidents Idrissa Seck and Macky Sall, both of whom used to be Wade's closest allies. One after the other they fell out of favour and formed their own political parties. The existence of a large number of political parties may be seen as a sign of a vibrant society. In Senegal, however, most of the approximately 100 parties are small and weak, presenting no credible programmatic appeal and confined to the larger cities. Rather than structuring vote choices, this multiplicity is confusing to voters.

The opposition made various attempts to present a united front for the 2012 elections but was unable to overcome infighting. As a result, 12 presidential candidates entered the contest, which was overshadowed by violent clashes between opposition groups and security forces. No winner emerged in the first round. As a result, a run-off election between Wade and Macky Sall, the bestplaced opposition candidate, was held and eventually won by Sall. Later, the coalition Benno Bokk Yakar, led by Sall, won the legislative elections.

\section{Stable Roots}

Voting patterns in Senegal are relatively unstructured, and it is difficult to align the parties with social cleavages. In fact, there is a strong tendency for all regions to follow identical trends. Until the end of the 1990s, support for the PS was overwhelming across the country. In 2001 the PDS swept the votes in all regions but suffered great losses in 2012.

As mentioned earlier, Senghor was eager to incorporate every important Senegalese community into clientelistic relationships with the state. As a consequence, a tradition of not appealing to ethnic identities in partisan politics developed. This does not mean that the living conditions of all groups are equal. In fact, there is a difference in regional development between the more highly developed and densely populated Western Senegal - roughly coinciding with the zone in which the Wolof, Senegal's largest ethnic group, lives - and the more remote, peripheral areas with thin population density. Interestingly, however, this has not greatly influenced party formation; ethnicity has always remained a negligible factor in Senegalese politics.

There are two main reasons for this. First, the existence of the Islamic Sufi brotherhoods has had an integrative and balancing effect that breaks through ethnic identity barriers. The brotherhoods 'have enough mutual recognition to amount to a single cultural group' (Cruise O'Brien, 2003: 121). The second factor is what Cruise O'Brien (1998) has called the 'shadow-politics of Wolofization'. According to this view, the boundaries of the Wolof group are blurred and regularly crossed by migrants adopting the Wolof language and culture as their own (Cruise O'Brien, 1998).

In the Afrobarometer data ethnic groups are almost evenly distributed among the potential voters of the PDS, PS, and AFP (see Figure 2). ${ }^{9}$ The ethnic composition of the PDS mirrors almost exactly that of the country as a whole. ${ }^{10}$

The slightly higher proportions of Serer in the PS and Wolof in the AFP are due to regional dynamics. The AFP has its stronghold in the mainly Wolof-populated department Kaolack, home region of party founder Niasse. The higher proportion of Serer in the PS can be explained by the fact that the party is now concentrating its campaigning efforts in Thiès, the second largest city in Senegal, where a large number of Serer live. Thus none of the three parties can be directly connected to an ethnic clientele. 


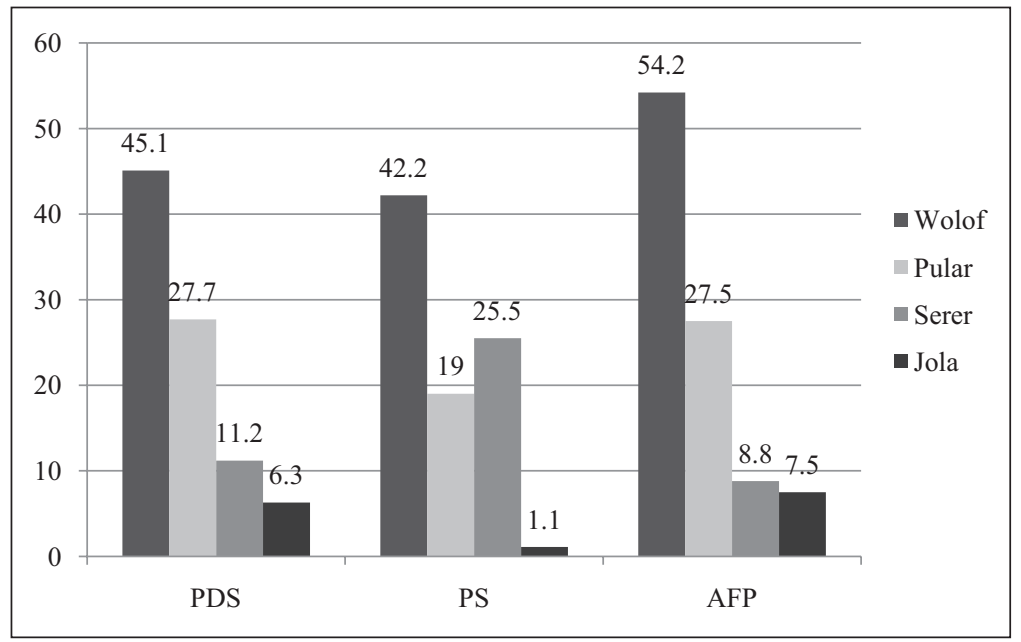

Figure 2. Ethnicity and voting behaviour in Senegal (in \%).

With regard to living conditions and other socio-economic factors, we find few differences between the sympathizers of the three parties in the Afrobarometer data (see Table 6).

Table 6. Living conditions and voting behaviour in Senegal (in \%).

\begin{tabular}{lcll}
\hline & Good & Neither good nor bad & Bad \\
\hline PDS voters & 8.4 & 22.8 & 68.9 \\
PS voters & 10.4 & 18.6 & 60.2 \\
AFP voters & 5.8 & 8.7 & 85.5 \\
\hline
\end{tabular}

As the table suggests, there is some variance, but the differences run counter to the intuition that the poor would sympathize with the opposition. In fact, AFP voters are the poorest, while supporters of the PS are somewhat better off than all others. Overall, there is no clear association between living conditions and voting patterns.

Neither ethnic nor socio-economic factors sufficiently explain voting patterns. The most important cleavage in voting seems to be the urban/rural divide. As an opposition politician, Wade was originally the hero of the urban youth; the PDS used to have its greatest electoral success in the capital Dakar and the surrounding area. In recent years, however, the party has ceased to be the voice of the cities. In 2012 the party lost almost all bigger cities to the Coalition Benno Bokk Yakaar and instead achieved its best results in rural areas. Although this may seem paradoxical, it highlights a widespread problem: keeping up-to-date with the latest news from political parties requires good access to information, which is often lacking in the countryside. Rural voters may be tempted to vote for candidates and parties they are most familiar with, even when these parties do not best represent their interests.

Finally, what role do ideologies play? There are two broad camps: the socialists and the liberals. This dichotomy dates back to the ideological prescriptions of the multipartism limité. At that time, the PS reserved the term 'socialist' for itself, and the PDS was left with the label of 'liberal', even though the original ideological conception of the party was closer to socialism than liberalism. The 
Table 7. Trust in political parties in Senegal (in \%).

\begin{tabular}{lll}
\hline & Ruling party (PDS) & Opposition parties \\
\hline A lot & 22.7 & 20.0 \\
Just a little/somewhat & 34.1 & 47.6 \\
Not at all & 44.7 & 32.0 \\
\hline
\end{tabular}

fact that the PDS adopted the label of liberal so quickly suggests that the ideological orientation does not carry much weight. Later, the party seemed to have fully embraced liberalism, at least rhetorically, and even joined the Liberal International federation. In the field interviews, party officials insisted on their liberal orientation, but many inconsistencies were in evidence. Leading officials underlined the fact that the PDS was both a liberal and a social party, and that individual freedoms required a certain degree of social justice. ${ }^{11}$ In Senegal, splinter groups tend to remain within the same ideological camp; as a result, the parties of Seck and Sall also have a liberal profile. The same can be said of the socialist groups: the PS has produced a number of new parties, most of which maintain social democracy as their ideology, one of them being the AFP. In the field interviews, PS and AFP officials alike stressed the fact that their parties belonged to the same ideological family and that their split was only due to leadership issues. However, in both cases, the socialist programmatic appeal was expressed in very broad and general terms. All in all, there was no clearly defined ideological competition between the parties, and labels such as 'liberal' or 'social-democratic' appeared to lack substance.

\section{Legitimacy}

A slight majority of $54 \%$ of the Afrobarometer respondents feel close to one of the political parties. ${ }^{12}$ As Table 7 shows, the Senegalese mistrust the ruling party in particular. Opposition parties fare a bit better, but overall the figures for trust are lower than in Ghana. ${ }^{13}$

This finding is unsurprising, as the political climate has markedly deteriorated in recent years, and tensions between the government and opposition have been steadily rising. A first stage of escalation was reached in 2007, when the opposition accused Wade of electoral fraud in the presidential elections. As a consequence, the major opposition parties decided to boycott the subsequent legislative elections. Because of low turnout (34\%), these elections did not represent the will of the populace, but at the same time, the major opposition parties had effectively deprived themselves of any parliamentary representation. The opposition coalition Benno Siggil Senegal was relatively successful in the 2009 local elections. Wade, becoming aware of the emerging threat to his rule, tried to maintain his hold on power with a constitutional amendment designed to ensure his reelection. The draft of the amendment had to be withdrawn after mass demonstrations in June 2011, but the legality of Wade's candidacy for a third presidential term remained a subject of controversy. Massive demonstrations and violent incidents in the immediate run-up to the presidential elections in February 2012 raised fears about the future of Senegal's democracy. The peaceful transfer of power from Wade to Sall is an encouraging sign, but the legislative elections which are scheduled for June 2012 will nevertheless put the country to the next test.

\section{Party Organization}

Many Senegalese parties are weakly organized, and many of the smaller parties are restricted to urban areas. Party membership is especially difficult to assess in Senegal. Formal membership in 
a party normally requires the purchase of a party card, and although these cards are supposed to be sold annually, even this basic activity does not always take place with any regularity.

PS and AFP have almost the same organizational structure. The basic unit of the party is the comité, which consists of 50 to 100 members, followed by the section, the coordination, and the union régionale. The PS, which had a very extensive party apparatus in the past, has suffered the decay and decline seen in many other ex-ruling parties in Africa. Large numbers of members have defected from the PS to the PDS or to other splinter groups, while other members have sunk into passivity. After the near collapse in the first years of the alternance, the PS has embarked on a course of renewal and rebuilding of grassroots activism. This is truly necessary if the party wants to play a decisive role in Senegalese politics in the future. In Mbacké, for example, the local party consists primarily of elderly people who diligently carry out party work with great discipline, but in a fashion that may not be very appealing to the younger generation. The AFP, despite being a small party, is quite well-organized throughout the country. For example, in Thiès, party activities take place with regularity; the local party keeps membership statistics and has an office with a paid full-time secretary. Other locations, especially in rural Senegal, are more difficult for the party to reach; however, it is evident that the AFP is making considerable efforts to strengthen its organizational capacity.

While the opposition parties clearly suffer from a lack of resources, organizational problems in the PDS were home-made. Of all parties under examination, the PDS had the least-developed formal structure. In some locations, it was virtually absent or exhibited little activity. Even highranking party officials admit that there are organizational problems. ${ }^{14}$ To an extent, these organizational problems were caused by a phenomenon that in Senegal is referred to as 'political nomadism' (transhumance politique). After 2001, the PDS was overrun by a massive influx of new members, many of them patronage-seeking former PS officials. From a relatively small and urbanbased opposition party, the PDS was rapidly transformed into a large nationwide movement, but it was not able to sufficiently integrate the newcomers. Conflicts arose between the 'old guard', who had followed Wade on his long road to power, and an ambitious new generation. To an extent it seems that Wade's personalistic leadership style was caused by the need of holding the ranks together. At the same time, however, it creates tensions within the upper ranks of the party and accelerated its organizational degeneration. An interesting example is the city of Thiès, which was a party stronghold in 2001. This comparatively well-organized local branch was totally paralysed by the rupture with Idrissa Seck, and the majority of local members crossed over to his new Rewmi party. What actually remains of the PDS in Thiès is little more than a fan club for Abdoulaye Wade. All formal and informal structures of the party are centred on him, the executive committees of the party are tightly under his personal control, and meetings of the highest party committees take place only when he personally convenes them.

Personalism has reached extreme levels in the PDS, but it is also prevalent in the other political parties in Senegal. Senegalese parties are often synonymous with their leaders; in everyday language, the PDS is 'the party of Abdoulaye Wade', the AFP is 'the party of Moustapha Niasse', and so on. All interviewed party officials made frequent reference to the qualities and virtues of their leaders, which appeared to be more important than the party labels.

\section{Conclusion}

The case studies support the hypothesis that higher levels of PSI are positively related to higher levels of democratic quality. Ghana scores higher than Senegal on all four indicators of party institutionalization. The findings are summarized in Table 8 .

Political competition in Ghana takes place primarily between the NPP and the NDC. This twoparty system is the product of a path-dependent development that began with a split in the 
Table 8. Summary of findings.

\begin{tabular}{|c|c|c|}
\hline & Ghana & Senegal \\
\hline \multirow{2}{*}{ Regularity } & $\begin{array}{l}\text { Various military and civilian } \\
\text { governments, but long-standing party } \\
\text { traditions }\end{array}$ & $\begin{array}{l}\text { Multiparty elections since 1976, but long } \\
\text { dominance of the PS, later dominance of } \\
\text { the PDS }\end{array}$ \\
\hline & $\begin{array}{l}\text { Two-party system, low number of } \\
\text { parties, high stability }\end{array}$ & $\begin{array}{l}\text { Dominant party system, excessive party } \\
\text { proliferation, instable and fluid }\end{array}$ \\
\hline \multirow[t]{2}{*}{ Stable roots } & Polarization, centre-periphery conflict & Low representation of social cleavages \\
\hline & $\begin{array}{l}\text { Parties have definable and stable } \\
\text { support bases (ethnic, regional, socio- } \\
\text { economic, ideological) with historical } \\
\text { roots }\end{array}$ & $\begin{array}{l}\text { Support bases scarcely definable, no } \\
\text { ethnic or socio-economic cleavages } \\
\text { (exceptions: local strongholds), diffuse } \\
\text { ideologies }\end{array}$ \\
\hline \multirow[t]{3}{*}{ Legitimacy } & Parties and elections widely accepted & $\begin{array}{l}\text { Growing mistrust in the ruling party } \\
\text { prior to } 2012 \text { elections }\end{array}$ \\
\hline & Opposition boycott in 1992 & Opposition boycott in 2007 \\
\hline & Parties respect democratic norms & $\begin{array}{l}\text { Tensions between government and } \\
\text { opposition, violence }\end{array}$ \\
\hline \multirow[t]{2}{*}{$\begin{array}{l}\text { Party } \\
\text { organization }\end{array}$} & $\begin{array}{l}\text { Major parties equally well organized, } \\
\text { nationwide presence, smaller parties } \\
\text { weak }\end{array}$ & $\begin{array}{l}\text { Organizational problems of smaller } \\
\text { opposition parties but also of the PDS }\end{array}$ \\
\hline & $\begin{array}{l}\text { Parties matter more than } \\
\text { personalities }\end{array}$ & Strong personalism, especially in the PDS \\
\hline PSI & Strongly institutionalized & Weakly institutionalized \\
\hline
\end{tabular}

independence movement. The Busia-Danquah tradition has historically represented one side of the conflict line, cementing this relationship with a perfectly adapted ideology of liberal democracy, elite orientation, and free-market economy. The other side was originally represented by Nkrumahism, with its appeal to ordinary people and hostility directed towards the elite and the Ashanti-dominated establishment. Gradually the NDC replaced the Nkrumahists, thus restoring the bipartisan nature character of Ghanaian politics. Because these political poles are deeply entrenched in the history of the country, parties do not rise and fall with the fate of individual leaders; rather, they can associate themselves with traditions that have proven to be even more durable than regimes and regime types. Moreover, each tradition has a distinctive support base. This provides voters with an orientation and gives parties an opportunity to produce diversified images: they can appeal to ethnic or regional identities or to the differences between elites and the common people, but also to voters who may be interested in ideologies.

The two-party system has two additional advantages. First, it provides an incentive to invest in party organization, because neither of the parties can win by mobilizing its core voters alone. It follows that a nationwide presence and a degree of organizational effectiveness are key for electoral success. Because better-organized parties can more effectively reach out to voters, this strengthens and reinforces the connection between citizens and the political process. Second, a party system with two almost equally strong poles decreases the likelihood of opposition boycott and non-cooperation. Election losers would gain little from not accepting results; rather, they would risk plunging the country into chaos. Furthermore, any losing candidate can still hope to make a comeback in the next election; respecting democratic procedures is not only a normative but also a rational calculation. This, in turn, sends a strong positive message to the electorate and enhances trust in parties and in the overall political process. 
In Senegal, in contrast, the party system appears to be more fluid and less predictable. It is characterized by leadership struggles, party splits, and a steadily rising number of new parties. With the exception of some local strongholds (usually the hometown of the party leader), no party has built up a well-defined support base, either in ideological or in socio-economic terms. Just as in Ghana, the path for this development was laid at an early stage. The integration of diverse social groups into a clientelistic relationship with the state guaranteed the predominance of the PS for many years. Opposition parties were legalized, but the inclusive clientelism together with the artificial ideological labels of the multipartism limité did not allow the opposition to align themselves with relevant social cleavages. In 2000, the PDS strongly benefitted from dissatisfaction with the PS simply by promising change. As a ruling party, however, the PDS never became more than just 'the party of Abdoulaye Wade'.

While personalism has reached extreme levels in the PDS, the syndrome is prevalent in all parties: because they do not represent identifiable social cleavages or different ideological conceptions, parties are built around the charismatic qualities of their leaders. This sets in motion a number of mutually reinforcing effects that ultimately have a negative impact on democracy. The Senegalese party system provides little orientation to voters. Loyalties are formed towards a person and not an organizational label; consequently, parties do not build effective linkages with citizens. Thus the victory of the Benno Bokk Yakaar Coalition in 2012 is merely an outcome of the pronounced dissatisfaction with the PDS. The party system in Senegal is still heavily fragmented and provides little orientation to voters. The weak linkage between parties and voters means that parties struggle to realistically assess their electoral chances, and the strong personalism makes it difficult to establish a political culture in which formal organizational rules really matter. If democracy is to flourish in Senegal, parties must become less personalized and develop clearly shaped programmatic appeals.

In summary, an institutionalized, well-structured party system in which relevant social cleavages are translated into electoral alternatives seems to be more conducive to democracy than a relatively unstructured, personalistic system in which no durable linkages between social groups and political parties have been built. This is not say that the Ghanaian party system is ideal, as the politicization of cleavages - especially between ethnic identities - entails its own dangers, and an overly institutionalized party system with frozen cleavages may also be detrimental to democracy in the long run. Overall, however, forging effective connections between parties and the electorate seems to be indispensible for countries in the process of democratization.

\section{Funding}

This research was funded by the German Research Foundation (DFG).

\section{Notes}

1. See UN data (2012a) and UN data (2012b) for basic economic and social indicators.

2. The Afrobarometer measures the social, political, and economic atmosphere in Africa. See www.afrobarometer.org.

3. This criterion was used by Kuenzi and Lambright (2001).

4. The question reads, 'Do you feel close to one of the political parties in your country?'.

5. The question reads, 'How much do you trust the following institutions?'.

6. Interview with Murtala Mohamed, Constituency Secretary NPP Cape Coast, Cape Coast, 3 March 2007.

7. This phrase is commonly used in Ghana to describe the loyalty of NDC voters.

8. In 2012 PS and AFP joined the Coalition Benno Bokk Yakaar.

9. For a description of the Afrobarometer questions used, see note 4. 
10. The Senegalese Statistical Service gives the following figures: Wolof $44.5 \%$, Pular $25.2 \%$, Serer $13.8 \%$, Jola 5\%, and some smaller groups.

11. Interview with Dib Thiare, Secretaire Permanent National, PDS, Dakar, 26 November 2007.

12. For a description of the Afrobarometer questions used, see note 4.

13. For a description of the Afrobarometer questions used, see note 5.

14. Interview with Lamine Ba, Secretaire Administratif Adjoint, PDS, Dakar, 30 October 2006.

\section{References}

Agence Nationale de la Statistique et de la Démographie (ANSD) (2004) Rapport de synthese se la deuxieme enquete senegalaise aupres des ménages [The second Senegalese househould survery synthesis report]. Available at: www.ansd.sn/publications/rapports_enquetes_etudes/enquetes/ESAM_2.pdf (accessed 2 March 2012).

Amponsah N (2006) Political traditions and electoral politics in Kintampo North and South, Sissala West and Wa Central. In: Boafo-Arthur K (ed.) Voting for Democracy in Ghana. Accra: Freedom Publications, 287-307.

Basedau M (2007) Do party systems matter for democracy? In: Basedau M, Erdmann G and Mehler A (eds) Votes, Money and Violence. Uppsala: Nordiska Afrikainstitutet, 105-143.

Basedau M, Erdmann G and Mehler A (2007) Conclusion. The research agenda ahead. In: Basedau, Erdmann G and Mehler A (eds) Votes, Money and Violence. Uppsala: Nordiska Afrikainstitutet, 276-293.

Bennett A and Elman C (2006) Complex causal relations and case study methods: The example of path dependence. Political Analysis 14: 250-267.

Cruise O'Brien D (1998) The shadow-politics of Wolofisation. Journal of Modern African Studies 36(1): 25-46.

Cruise O'Brien D (2003) Symbolic Confrontations: Muslim Imagining the State in Africa. London: Hurst \& Co.

Erdmann G (2004) Party research: Western European bias and the 'African labyrinth'. Democratization 11(3): 63-87.

Fatton R (1987) The Making of a Liberal Democracy: Senegal's Passive Revolution, 1975-1985. Boulder and London: Lynne Rienner Publishers.

Frempong AKD (2001) Ghana's election 2000: The ethnic undercurrent. In: Ayee JRA (ed.) Deepening Democracy in Ghana, Vol. 1. Accra: Freedom Publications, 141-159.

George A and Bennett A (2005) Case Studies and Theory Development in the Social Sciences. Cambridge: MIT Press.

Gyimah-Boadi E and Asante R (2004) Ethnic Structure, Inequality and the Governance of the Public Sector in Ghana. Geneva: UNRISD.

Hall PA (2003) Aligning ontology and methodology in comparative politics. In: Mahoney J and Rueschemeyer D (eds) Comparative Historical Analysis in the Social Sciences. Cambridge: Cambridge University Press, 373-406.

Huntington S (2006) Political Order in Changing Societies. New Haven, CT: Yale University Press. (Original work published 1968).

Jonah K (1998) Political parties and the transition to multi-party politics in Ghana. In: Ninsin KA (ed.) Ghana - Transition to Democracy. Dakar: CODESRIA, 83-107.

Karvonen L and Anckar C (2002) Party systems and democratization: A comparative study of the third word. Democratization 9(3): 11-29.

Kuenzi M and Lambright G (2001) Party system institutionalization in 30 African countries. Party Politics 7(4): 437-468.

Kuenzi M and Lambright G (2005) Party systems and democratic consolidation in Africa's electoral regimes. Party Politics 11(4): 423-446.

Levy JS (2008) Case studies: Types, designs, and logics of inference. Conflict Management and Peace Science 25: $1-18$.

Lieberson S (1992) Small N's and big conclusions. In: Ragin C and Becker HS (eds) What Is a Case? New York: Cambridge University Press, 105-118. 
Lindberg S (2007) Institutionalization of party systems? Stability and fluidity among legislative parties in Africa's democracies. Government and Opposition 42: 215-241.

Lindberg S and Morrison MKC (2005) Exploring voter alignments in Africa: Core and swing voters in Ghana. Journal of Modern African Studies 43(4): 565-586.

Lipset SM and Rokkan S (1967) Party Systems and Voter Alignments: Cross-National Perspectives. New York: Free Press.

Manning C (2005) Assessing African party systems after the third wave. Party Politics 11(6): 707-727.

Mainwaring S and Scully T (1995) Building Democratic Institutions: Party Systems in Latin America. Stanford, CA: Stanford University Press.

Mbow P (2008) Senegal: The return of personalism. Journal of Democracy 19: 156-169.

Mozaffar S and Scarritt JR (2005) The puzzle of African party systems. Party Politics 11: 399-421.

Nugent P Banknotes and symbolic capital. In: Basedau M, Erdmann G and Mehler A (eds) Votes, Money and Violence. Uppsala: Nordiska Afrikainstitutet, 252-275.

Randall V and Svåsand L (2002) Party institutionalization in new democracies. In: Party Politics 8: 5-29.

Sartori G (2005) Parties and Party Systems: A Framework for Analysis. Colchester: ECPR Press. (Original work published 1976).

UN data (2012a) Ghana. Available at: http://data.un.org/CountryProfile.aspx?crName=Ghana\#Economic (accessed 2 March 2012).

UN data (2012b) Senegal. Available at: http://data.un.org/CountryProfile.aspx?crName=Senegal (accessed 2 March 2012).

\section{Author biography}

Anja Osei received her PhD degree in 2010 from the African Studies Institute at the University of Leipzig. The project dealt with strategies of party voter-linkage in Ghana and Senegal and included extensive fieldwork in the two countries between 2006 and 2009. The project was founded by the German Research Foundation (DFG). She is currently holding a post-doc position at the University of Konstanz, Department of Politics and Management. Her research interests lie in the field of African politics and political sociology with a particular focus on democratization, state-society relations, and neopatrimonialism. She is preparing a new project which will deal with the political elites and their formal and informal networks in Africa. 